\title{
Wernicke's Encephalopathy in A Young Adult Affected by T Cell Acute Lymphoblastic Leukemia and Ileotiphlytis with Review of the Literature Becilli $\mathbf{M}^{1 * \#}$, Pagano ${ }^{1 * \#}$, Mallio CA $^{2}$, Annibali $\mathbf{O}^{1}$, Armiento $D^{1}$, Scardocci A $^{1}$, Sala SWD ${ }^{2}$ and Avvisati G ${ }^{1}$ \\ ${ }^{1}$ Unit of Hematology, Transfusion Medicine and Cell Therapy, University Campus Bio-Medico, Rome, Italy \\ ${ }^{2}$ Unit of Diagnostic Imaging, University Campus Bio-Medico, Rome, Italy \\ ${ }^{\#}$ Authors contributed equally to this work
}

\begin{abstract}
Wernicke-Korsackoff Syndrome is a potentially fatal neurological complication caused by a deficiency of thiamine. The clinical diagnosis is a challenge and the syndrome is frequently misdiagnosed. In this paper we describe the case of a young man affected by T-ALL and ileotyphlitis who developed Wernicke's Encephalopathy after a month of total parenteral nutrition. Neurological symptomatology, consisting of confusion, nystagmus on lateral gaze, impairment of consciousness state, prosopagnosia and weakness in the four limbs, appeared progressively. An MRI of brain permitted to confirm the diagnosis and high-dose thiamine reintegrating therapy was started obtaining complete resolution of the syndrome.
\end{abstract}

Keywords: Wernicke's encephalopathy; Thiamine; Vitamin B1; Leukemia; Total parenteral nutrition

\section{Introduction}

Wernicke-Korsackoff Syndrome is defined as a potentially fatal neurological complication caused by a deficiency of thiamine (Vitamin $\mathrm{B}_{1}$ ) and is considered a real neurological emergency. The natural history of this syndrome presents two different stages: a) the Wernicke's Encephalopathy (WE), the acute phase of the syndrome which needs a prompt treatment by the reintegration of thiamine and b) the Korsackoff's psychosis, considered the chronic evolution of the neurological condition [1]. The majority of the clinical cases are related to a persistent alcoholic abuse [2], but it is not infrequent to find cases nonalcohol dependent [3]. Indeed, some risk factors, such as malnutrition, produce in Central Nervous System (CNS) the pathological alteration typical of the syndrome [4]. The WE is characterized by a classic triad: encephalopathy, oculomotor dysfunction and gait ataxia. Rarely the whole triad is present in the same patient $[1,5]$. Therefore, the clinical diagnosis is hard; as a consequence, the syndrome is still significantly missed. Laboratory tests and neuroimaging help in the differential diagnosis and confirm the suspect [6].

We report a case of a young man affected by T-Cell Acute Lymphoblastic Leukemia (T-ALL) who, following a month of total parenteral nutrition (TPN), developed the Wernicke's Encephalopathy.

\section{Case Report}

Our case is a 28 -year-old man affected by T-ALL diagnosed in August 2014. The patient achieved a complete remission of the disease after an induction therapy according to the BFM90 protocol [7]. Starting from November 2015, a maintenance therapy with methotrexate and 6-mercaptopurine was initiated and after a month the patient was admitted in our Department complaining diarrhoea and vomiting associated to anorexia and loss of weight. In order to define the cause, routine blood exams were requested in addition to laboratory stool test seeking for commonly diarrhoea-associated bacteria and microbiological tests demonstrated the presence of C. difficile and its toxins. Abdominal CT scan revealed an acute ileotyphlitis characterised by a stratified concentric edematous thickening of the colon walls. Following a consultation with a specialist in infectious diseases, a complete fasting associated to a TPN without the addiction of vitamins was begun. The antibiotic therapy consisted of oral vancomycin and intravenous metronidazole. After a two-week period of TPN a new laboratory stool test was carried out, revealing a persistent positivity for both the antigen and the toxin of $C$. difficile. Furthemore, a radiological evidence of the ileotyphlitis endured. Therefore, it was recommended to continue a complete fasting and the TPN. Seven days later, a third laboratory stool test revealed the absence of the $C$. difficile toxin associated to an improvement in the abdominal pain. Nevertheless, the patient began to refer a mild neurological symptomatology consisting of diplopia, especially during the lateral gaze, and headache. Hearing loss, horizontal nystagmus and a severe mental sluggish appeared. The neurological examination showed hyperactive osteotendinous reflexes, muscular hypotonia and hypotrophy, with preserved strength of limbs. Sensitivity disorders were not observed. During the following days, clinical evaluations showed a rapid and progressive decline of the neurological condition up to a status characterized by lethargy, confusion and space-time disorientation. Due to these observations, brain and abdomen TC were performed. Ileotyphlitis was confirmed, but no significant cerebral abnormalities were detected. In the meantime, bone marrow aspiration and spinal tap were performed in order to exclude a relapse of the hematologic malignancy. Morphological and immunophenotypical analysis of bone marrow aspirate and of cerebrospinal fluid excluded a relapse of T-ALL. Nevertheless, the patient's clinical conditions worsened by the appearance of fever, shaking chills, tachycardia and low blood pressure. These signs and symptoms, initially referred to a sepsis, did not modify

*Corresponding authors: Marco B, Unit of Hematology, Transfusion Medicine and Cell Therapy, University Campus Bio-Medico, Rome, Italy, Tel: +39-06-22541 1124/+39-331-7875189; Fax: +39-06-22541-1933; E-mail: m.becilli@unicampus.it

Anastasia P, Unit of Hematology, Transfusion Medicine and Cell Therapy, University Campus Bio-Medico, Rome, Tel: +39-06-22541-1124/+39-349-8538151; Fax: +3906-22541-1933; E-mail: a.pagano@unicampus.it

Received November 27, 2017; Accepted November 29, 2017; Published December 02, 2017

Citation: Becilli M, Pagano A, Mallio CA, Annibali O, Armiento D, et al. (2017) Wernicke's Encephalopathy in A Young Adult Affected by $\mathrm{T}$ Cell Acute Lymphoblastic Leukemia and Ileotiphlytis with Review of the Literature. J Blood Lymph 7: 182. doi: 10.4172/2165-7831.1000182

Copyright: ( $\odot 2017$ Becilli M, et al. This is an open-access article distributed under the terms of the Creative Commons Attribution License, which permits unrestricted use, distribution, and reproduction in any medium, provided the original author and source are credited. 
despite the empiric antibiotic therapy and therefore Liposomal amphotericin B was added. In the meantime, TPN was discontinued and normal saline solution $0.9 \%$ ( $2000 \mathrm{~mL} / 24$ hours) was begun. Two days after the initiation of antifungal therapy fever disappeared and TPN was resumed. However, new neurological symptoms appeared: prosopagnosia, accentuated nystagmus on lateral gaze, weakness in the four limbs and confusion. A generalized seizure crisis followed by cardiac arrest was promptly resolved with basic life support, even though the state of consciousness worsen with the appearance of drowsiness. In the suspect of a meningoencephalitis, the following diagnostic procedures were performed: EEG and MRI of brain, lumbar puncture for cytology, chemical-physical and microbiological examinations. The CSF revealed an increase in total protein level $(723 \mathrm{mg} / \mathrm{dL}$; n.v.: $150-450$ $\mathrm{mg} / \mathrm{dL}$ ) associated to normal albumin concentration, glucose level and WBC count. The microbiological examinations on CSF were negative for the presence of bacteria, fungi and viruses. MRI of the brain (Figure 1A-C) showed a bilaterally and symmetric mild swelling and sharp high signal of mammillary bodies, quadrigeminal colliculus, dorsal medial thalami portions, mesencephalon tectum and periaqueductal/ periventricular regions around the forth ventricle and linear high signal near pia mater in the interpeduncolar cistern on T2 and FLAIR images, with a restricted diffusion and a mild enhancement after gadolinium administration in the same areas. Furthermore, a moderate high signal at cortical-subcortical temporo-insular cortex bilaterally, compatible with post-critical vasogenic oedema, were observed on the same images. Therefore, the radiologist excluded the possibility of meningoencephalitis and proposed a Wernicke Encephalopathy diagnosis. Following this suggestion, as the diagnosis of Wernicke
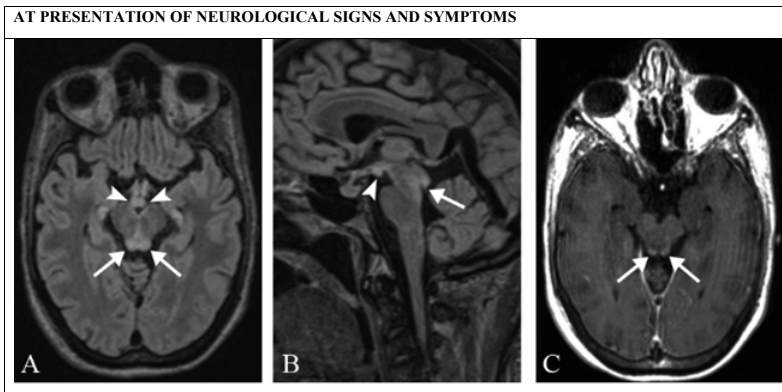

AFTER THIAMINE SUPPLEMENTATION
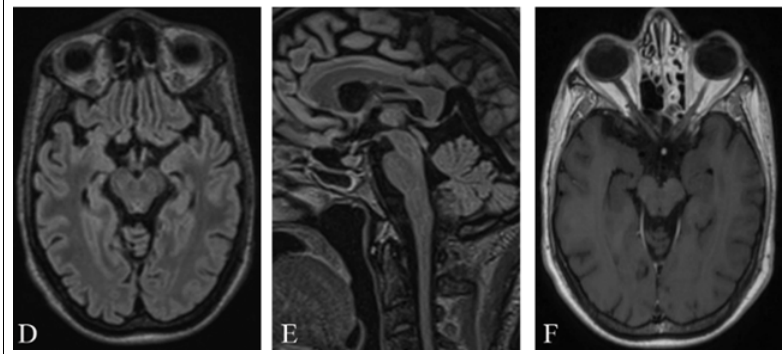

Figure 1: Brain MRI obtained with axial ( $A$ and $D)$ and sagittal ( $B$ and $E)$ FLAIR images and axial gadolinium-enhanced T1 images ( $C$ and $F)$. Symmetric high signal intensity and swelling are shown at the tectum of the midbrain and the periaqueductal regions (white arrows in $A$ and $B$ ) as well as at the mamillary bodies (white arrowheads in A and B); on sagittal FLAIR image a mild stenosis of the sylvian aqueduct is detectable (white arrow in B). Symmetric and fain post-gadolinium signal enhancement is also present at the periaqueductal regions (white arrow in $\mathrm{C}$ ).

The findings are indicative of Wernicke encephalopathy.

The follow-up brain MRI, performed one month after thiamine replacement, shows a complete regression of all the abnormalities ( $D, E$ and $F$ ).
Encephalopathy is mainly clinical with the support of neuroimaging for differential diagnosis, high-dose thiamine reintegrating therapy was started. It was decided to administer $500 \mathrm{mg}$ intramuscular injection three times a day for the first three days, and then $500 \mathrm{mg}$ twice a day for the following two days. General and neurological status improved dramatically after the first thiamine doses. In addition, abdominal pathological condition normalized soon and patient gradually returned to eat autonomously so that TPN was discontinued and the patient was rapidly discharged, with oral therapy consisting of thiamine 500 mg twice a day. During the administration of thiamine, we tested Vitamin B1 levels, which resulted in the normal range $(162.5 \mathrm{mmol} / \mathrm{l}$; n.v.: $66.5-200 \mathrm{mmol} / \mathrm{l})$. One month after the beginning of therapy with thiamine, the patient underwent a new MRI of brain showing a sharp improvement of the neuroimaging condition, specifically with a nearly complete regression of abnormal high signal and symmetrical bilateral swelling of mammillary bodies, quadrigeminal colliculus, dorsal medial thalami portions, mesencephalon tectum and periaqueductal/ periventricular regions around the forth ventricle on T2 images (Figure 1D-F). In addition, diffusion restriction and the abnormal postcontrastographic enhancement were no more appreciable. A complete neurological evaluation underlined the resolution of the signs and symptoms previously described with the presence of a mild gait ataxia, and thiamine oral integration was discontinued.

\section{Discussion}

Thiamine, also known as vitamin $B_{1}$, is a water-soluble vitamin of the $\mathrm{B}$ complex. It is synthetized by bacteria, fungi and plants and is an essential component of multicellular living organisms. Humans are not able to produce this vitamin and have to obtain it from different foods [8]. Thiamine is found in larger quantities in food such as yeast, legumes, pork and cereals. Its requirements for humans are generally expressed as absolute values per day (1.1-1.2 mg/d) or in relation to caloric intake $(0.5 \mathrm{mg} / 1000 \mathrm{Kcal})$ [9-12]. It is absorbed through bowel walls, mainly in the jejunum and ileum tracts, via both passive diffusion and active transport [9]. At low concentrations, the process is carriermediated, through a sodium and ATP-dependent pump, while, at higher concentrations, absorption occurs via passive diffusion that is specifically inhibited by alcohol consumption and by folic deficiency [8]. The majority of thiamine in serum is bound to proteins, mainly albumin. It enters erythrocytes by passive diffusion, while its entry in other cells happens through an energy-requiring process. Human storage of thiamine is about 25 to $30 \mathrm{mg}$, with the greatest concentrations found in skeletal muscle, heart, brain, liver, and kidneys. Thiamine's half-life is 10-20 hours and, for this reason and because of limited tissue storage, a continuous intake is needed [9]. About $80 \%$ of intracellular thiamine is phosphorylated, forming various derivatives, like thiamine pyrophosphate (TPP) and thiamine monophosphate (TMP). Thiamine and all of its metabolites are excreted in the urine [9]. TPP, also known as thiamine diphosphate (ThDP), is the main thiamine metabolite and its activities are well characterized. Its synthesis is catalyzed by thiamine diphosphokinase. As a coenzyme, TPP is involved in many cellular metabolic activities, like the transketolation of the pentose phosphate pathway and the oxidative and non-oxidative decarboxylation of alpha-keto acids by dehydrogenase complexes [10]. Furthermore, thiamine has a role in the initiation of nerve impulse propagation and this action is independent of its coenzyme functions [9]. Considering that TPP as a coenzyme catalyzes the activity of enzymes mainly involved in the metabolism of carbohydrates, it appears obvious that thiamine status is closely related to the intake of carbohydrates. Therefore, an increased amount of carbohydrates can cause a decrease of plasma and urine levels of thiamine, without affecting enzymes 
Citation: Becilli M, Pagano A, Mallio CA, Annibali O, Armiento D, et al. (2017) Wernicke's Encephalopathy in A Young Adult Affected by T Cell Acute Lymphoblastic Leukemia and lleotiphlytis with Review of the Literature. J Blood Lymph 7: 182. doi: 10.4172/2165-7831.1000182

activities [11]. Thiamine status can be assessed by measuring blood thiamine concentration, erythrocyte thiamine transketolase (ETKA), or transketolase urinary thiamine excretion [12]. The normal range for blood thiamine concentration is approximately 3.0 to 7.7 micrograms/ $\mathrm{dL}$ [8]. Thiamine metabolites and thiamine-dependent enzymes are present in all the body cells, thus a thiamine deficiency can adversely affect all the organs. However, the nervous system is particularly sensitive to thiamine deficiency, because of its dependence on oxidative metabolism. In particular, thiamine deficiency has been associated with three syndromes: Beriberi, Wernicke-Korsakoff syndrome and Leigh's syndrome.

Several risk factors have been identified for Wernicke's encephalopathy (WE). The most important is alcohol abuse. In non-alcoholic patients, the major conditions associated are AIDS, malignancies, hyperemesis gravidarum, surgery (particularly surgical patients who underwent gastric bypass), prolonged total parenteral nutrition and iatrogenic glucose loading in any predisposed patient $[13,14]$. The recommended dose of thiamine (in an average and healthy adult) is $0.5 \mathrm{mg} / 1000 \mathrm{kcal}$ consumed or $1.4 \mathrm{mg} / \mathrm{die}$, and, in patients receiving a strict thiamine-free diet, 2-3 weeks are needed to determine a depletion [12,15-18]. Furthermore, WE seems to appear more quickly when TPN is administered in hypoalbuminemic patients [13]. In our case, three of these conditions were present: blood neoplasm, prolonged total parenteral nutrition and dextrose infusion. $\mathrm{WE}$ is a non-rare complication in patients affected by malignancies (Table 1). In Table 1 is reported a case series of patients affected by leukemia and with malnourishment of variable origin. Hematopoietic Stem Cell Transplantation increases the risk of this syndrome, particularly in patients experiencing Graft Versus Host Disease involving gastrointestinal tract with diarrhoea and vomit $[15,16]$ Patients affected by neoplasms are at high risk to develop a thiamine deficiency, because they are often malnourished as a consequence of chemotherapy or disease itself. Clinicians should consider WE

\begin{tabular}{|c|c|c|c|c|c|}
\hline Sex/age/diagnosis & Risk factors & $\begin{array}{l}\text { Time of neurological } \\
\text { manifestation }\end{array}$ & Treatment & Outcome & Bibliography \\
\hline Male/28 years/T-ALL & $\begin{array}{l}\text { Ileotyphlitis+one-month fasting and TPN } \\
\text { without vitamins for a month }\end{array}$ & After 22 days of TPN & $\begin{array}{l}\text { Thiamine } \\
\text { administration* }\end{array}$ & $\begin{array}{l}\text { Progressive improvement of the } \\
\text { neurological signs and symptoms } \\
\text { and resolution of the neuroimaging } \\
\text { condition }\end{array}$ & Our Case \\
\hline $\begin{array}{l}\text { Female/12 years/ } \\
\text { AMLABMT }\end{array}$ & $\begin{array}{l}\text { Malnutrition stemming from persistent loss } \\
\text { of appetite as a result of chemotherapeutic } \\
\text { agents or the leukemia itself }\end{array}$ & $\begin{array}{l}6 \text { months prior the } \\
\text { admission }\end{array}$ & $\begin{array}{l}\text { Thiamine } \\
\text { administration* }\end{array}$ & $\begin{array}{l}\text { Ocular palsy resolved completely the } \\
\text { day after thiamine integration was } \\
\text { started }\end{array}$ & $\begin{array}{l}\text { Ghorbani et al. } \\
\text { [19] }\end{array}$ \\
\hline Male/20 years/T-ALL & $\begin{array}{l}\text { Diet of only soda pop over the six months } \\
\text { preceding the admission }\end{array}$ & $\begin{array}{l}\text { Over the prior two weeks } \\
\text { he presented to the ER }\end{array}$ & $\begin{array}{l}\text { Thiamine } \\
\text { administration* }\end{array}$ & Progressive improvement & $\begin{array}{l}\text { Lacasse and } \\
\text { Lum [20] }\end{array}$ \\
\hline $\begin{array}{l}\text { Male/12 years/AML } \\
\text { (With CNS involvement) }\end{array}$ & $\begin{array}{l}\text { After the first course of chemotherapy } \\
\text { induction nausea, food refusal, persistent } \\
\text { vomiting strongly resistant to conventional } \\
\text { antiemetic therapy. Because of grade IV } \\
\text { mucositis TPN, without a multivitamin } \\
\text { supplementation. }\end{array}$ & After 30 days of fast: & $\begin{array}{l}\text { Thiamine } \\
\text { administration* }\end{array}$ & $\begin{array}{l}\text { Progressive improvement of } \\
\text { lethargic state, hypoacusia, visual } \\
\text { allucinations. } \\
\text { Recovering of diplopia and } \\
\text { nystagmus took longer. } \\
\text { Disappearance of characteristic } \\
\text { lesions at MRI of brain after } 2 \\
\text { months. }\end{array}$ & $\begin{array}{l}\text { La Spina, et al. } \\
{[21]}\end{array}$ \\
\hline $\begin{array}{l}\text { Male/45 years/CML } \\
\text { Ph1+/ABMT }\end{array}$ & $\begin{array}{l}\text { Acute GvHD of skin and liver (grade III) } \\
\text { treated with high doses of steroids and } \\
\text { cyclosporine A, and put on TPN }\end{array}$ & After 22 days of TPN: & $\begin{array}{l}\text { Thiamine } \\
\text { administration* }\end{array}$ & $\begin{array}{l}\text { Important improvement of the } \\
\text { neurological signs and symptoms } \\
\text { after } 2 \text { days of therapy. } \\
\text { Minimal residual lesion in the left } \\
\text { periventricular region at MRI of brain } \\
\text { after one month of therapy. }\end{array}$ & $\begin{array}{l}\text { Messina, et al. } \\
{[22]}\end{array}$ \\
\hline $\begin{array}{l}\text { Man/ } 35 \text { years/T-ALL/ } \\
\text { ABMT }\end{array}$ & $\begin{array}{l}\text { Severe gastric haemorrhage with anemia } \\
\text { and thrombocytopenia: from that moment } \\
\text { complete fast and put on TPN }\end{array}$ & $\begin{array}{l}\text { Thirteen days after the } \\
\text { beginning of TPN: }\end{array}$ & $\begin{array}{l}\text { Thiamine } \\
\text { administration* }\end{array}$ & $\begin{array}{l}\text { Rapid resolution of clinical } \\
\text { symptoms. }\end{array}$ & \\
\hline $\begin{array}{l}\text { Female/49 years/ALL } \\
\text { Ph+/ABMT }\end{array}$ & $\begin{array}{l}\text { Diarrhoea secondary to biopsy-confirmed } \\
\text { graft versus host disease (GVHD) and } \\
\text { anorexia. }\end{array}$ & $\begin{array}{l}\text { During the hospitalization } \\
\text { she became delirious } \\
\text { with encephalopathic } \\
\text { features over the course } \\
\text { of } 3 \text { to } 4 \text { days }\end{array}$ & $\begin{array}{l}\text { Thiamine } \\
\text { administration* }\end{array}$ & $\begin{array}{l}\text { Dramatic improvement of mental } \\
\text { status within } 12 \text { hours since the } \\
\text { beginning of thiamine integration } \\
\text { At re-evaluation mental status } \\
\text { excellent and not deteriorated }\end{array}$ & Steinberg [23] \\
\hline $\begin{array}{l}\text { Male/ } 16 \text { years/Pre-B } \\
\text { ALL }\end{array}$ & $\begin{array}{l}\text { During maintenance therapy, and after } \\
\text { receiving L-asparaginase (part of the } 2 \text { nd } \\
\text { re-induction course at week } 17) \text { : } \\
\text { Acute pancreatitis (with fever, vomiting and } \\
\text { severe abdominal pain). } \\
\text { Patient kept fasting, iv antibiotics and TPN } \\
\text { (no intravenous multivitamin preparations) }\end{array}$ & After 14 days of TPN & $\begin{array}{l}\text { Thiamine } \\
\text { administration* }\end{array}$ & $\begin{array}{l}\text { Neurological symptoms and signs } \\
\text { improved rapidly and after two days } \\
\text { disappeared completely. }\end{array}$ & $\begin{array}{l}\text { Muwakkit et al. } \\
{[24]}\end{array}$ \\
\hline $\begin{array}{l}\text { Male/ } 34 \text { years/ALL } \\
\text { Ph+/UCBT }\end{array}$ & Acute GVHD (stage III-IV) of the gut & $\begin{array}{l}149 \text { days following } \\
\text { transplant }\end{array}$ & $\begin{array}{l}\text { Thiamine } \\
\text { administration* }\end{array}$ & $\begin{array}{l}\text { Two months following thiamine } \\
\text { replacement } \\
\text { the patient was conversant with } \\
\text { improvement } \\
\text { in personality at follow up but } \\
\text { remained forgetful without } \\
\text { complete resolution of symptoms. }\end{array}$ & Trueg et al. [25] \\
\hline
\end{tabular}

Table 1: Summary of previous cases of Wernicke's Encephalopathy in patients affected by Leukemia.

*Dosage varied from $50 \mathrm{mg}$ daily to $500 \mathrm{mg}$ tid. Thiamine generally administered IV or IM at induction phase and p.o. after the improvement of mental conditions. T-ALL: T-Cell Acute Lymphoblastic Leukemia; AML: Acute Myeloid Leukemia; ABMT: Allogenic Blood Marrow Transplantation; UCBT Umbelical Chord Blood Transplant; CNS: Central Nervous Systems; GVHD: Graft Versus Host Disease; TPN: Total Parenteral Nutrition; MRI: Magnetic Resonance Imaging. 
Citation: Becilli M, Pagano A, Mallio CA, Annibali O, Armiento D, et al. (2017) Wernicke's Encephalopathy in A Young Adult Affected by T Cell Acute Lymphoblastic Leukemia and lleotiphlytis with Review of the Literature. J Blood Lymph 7: 182. doi: 10.4172/2165-7831.1000182

Page 4 of 5

in the differential diagnosis of oncology and haematology patients affected by malignancies who develop neurological symptoms while in remission after intensive chemotherapy, especially if their nutrition is unbalanced. Nevertheless, this syndrome continues to be unrecognised and misunderstood [17]. Even if neuroimaging can have a role of confirmation showing lesions and signal alterations in typical sites, the diagnosis remains clinical. Laboratory analysis such as blood thiamine concentration and measurement of red blood cell transketolase activity are limited by a lack of sensitivity and specificity. No specific diagnostic abnormalities have been recognized in cerebrospinal fluid, electroencephalogram and evoked potentials [17]. Moreover, rarely the whole triad (altered mental status, ophthalmoplegia and gait ataxia) occurs in the same patient and occasionally arises simultaneously. If we consider singularly each element, altered mental status might be present in $82-90 \%$ of patients, ataxia in $23-70 \%$, ophthalmoplegia or nystagmus in $29-93 \%$. All this events make the suspect of this condition arduous. The prescription of adequate doses of parenteral thiamine integration produces a dramatic response of neurological signs. Indeed it has to be promptly adopted in every case WE is probable. In this case, chemical analyses of CSF could be suspicious for meningoencephalitis. However, the combination of neurological manifestations and radiological signs in MRI was highly suggestive for WE. Therefore, parenteral thiamine integration was rapidly begun; as a consequence the concentration of thiamine in serum performed after thiamine initiation resulted normal. The optimum dose and duration of thiamine treatment is still unknown and have to be defined by further studies. We started administering 500 $\mathrm{mg}$ of $\mathrm{B}_{1}$-vitamin three times a day for the first three days and then twice a day until the resolution of brain damages at MRI re-evaluation. Neurological conditions improved dramatically and very rapidly after the first doses. It is important to underline that parenteral thiamine infusion is safe, even with high levels of vitamin, and the response generally is excellent whether the diagnosis is correct. Furthermore, it must be kept in mind that many patients with WE have a normal MRI. For this reasons, the beginning of thiamine integration in patients with symptoms suggestive for $\mathrm{WE}$ and the presence of at least one risk factor appears to be recommended. As mentioned previously, Vit $B_{1}$ status in adults depends on carbohydrates intake. A study led by the Institute of Nutritional Science of the University of Vienna demonstrated how increasing the percentage of carbohydrates in the total caloric intake from $55 \%$ to $65 \%$, and then to $75 \%$, determines a reduction of plasma and urine levels of thiamine [11]. Therefore, an elevated intake of carbohydrates may increase thiamine requirements. In hospitalized patients, $5 \%$ dextrose solution is commonly used as maintenance fluid, this was the case in our patient who rapidly deteriorated neurological conditions leading to WE associated to epileptic seizure followed by an enduring comatose state after the administration of intravenous $5 \%$ dextrose solution following more than a month-period of TPN without thiamine integration. In conclusion, physician's knowledge of this syndrome is vital because its nonrecognition determines severe neurologic morbidity and possible mortality of patients, while prompt beginning of the right treatment is effective and lead to a complete recovery. The approach to a suspected Wernicke's encephalopathy must be "if in doubt, treat", because the administration of thiamine does not expose the patient to dangerous complications. Moreover, patients affected by malignancies, whom TPN has to be administered, must always receive an integration of parenteral Vitamin $B_{1}$ in order to prevent the appearance of this rare and severe complication that may mimic neoplastic meningosis.

\section{References}

1. Kopelman MD, Thomson AD, Guerrini I, Marshall EJ (2009) The Korsakof
Syndrome : Clinical Aspects, Psychology and Treatment. Alcohol Alcohol 44 148-154.

2. Leevy CM (1982) Thiamin deficiency and alcoholism. Ann N Y Acad Sci 378 316-326.

3. Scalzo SJ, Bowden SC, Ambrose ML, Whelan G, Cook MJ (2015) WernickeKorsakoff syndrome not related to alcohol use: a systematic review. J Neurol Neurosurg Psychiatry 86: 1362-1368.

4. Hargrave DD, Schroeder RW, Heinrichs RJ, Baade LE (2015) WernickeKorsakoff Syndrome as a Consequence of Delusional Food Refusal: A Case Study. Cogn Behav Neurol 28: 215-219

5. Harper CG, Giles M, Finlay-Jones R (1986) Clinical signs in the WernickeKorsakoff complex: a retrospective analysis of 131 cases diagnosed at necropsy. J Neurol Neurosurg Psychiatry 49: 341-345.

6. Sechi G, Serra A (2007) Wernicke's encephalopathy: new clinical settings and recent advances in diagnosis and management. Lancet Neurol 6: 442-455.

7. Schrappe M, Reiter A, Ludwig WD, Harbott J, Zimmermann M, et al. (2000) Improved outcome in childhood acute lymphoblastic leukemia despite reduced use of anthracyclines and cranial radiotherapy: results of trial ALL-BFM 90. Blood 95: 3310-3322.

8. Gubler CJ (1984) Thiamin. In: Handbook of vitamins: Nutritional, biochemical, and clinical aspects. Machlin LJ (Editor), New York, Marcel Dekker.

9. Davis R, Icke G, Thom J, Riley WJ (1984) Intestinal absorption of thiamin in man compared with folate and pyridoxal and its subsequent urinary excretion. J Nutr Sci Vitaminol (Tokyo) 30: 475-482.

10. Victor M, Adams RD, Collins GH (1989) The Wernicke-Korsakoff Syndrome and Related Neurologic Disorders Due to Alcoholism and Malnutrition (2 edn.), FA Davis.

11. Elmadfa I, Majchrzak D, Rust P, Genser D (2001) The thiamine status of adult humans depends on carbohydrate intake. Int J Vitam Nutr Res 71: 217-221.

12. Tan H, Farnell GF, Hensrud DD, Litin SC (1994) Acute Wernicke's Encephalopathy Attributable to Pure Dietary Thiamine Deficiency. Mayo Clin Proc 69: 849-850.

13. Francini-pesenti F, Brocadello F, Manara R, Santelli L, Laroni A, et al. (2009) Wernicke's syndrome during parenteral feeding: Not an unusual complication. Nutrition 25: 142-146.

14. Donnino MW, Vega J, Miller J, Walsh M (2007) Myths and Misconceptions of Wernicke's Encephalopathy: What Every Emergency Physician Should Know. Ann Emerg Med 50: 715-721.

15. Baek JH, Sohn SK, Kim DH, Kim JG, Lee HW, et al. (2005) Wernicke's encephalopathy after allogeneic stem cell transplantation. Bone Marrow Transplant 35: 829-830.

16. Steinberg A, Gorman E, Tannenbaum J (2014) Thiamine Deficiency in Stem Cell Transplant Patients: A Case Series with an Accompanying Review of the Literature. Clin Lymphoma Myeloma Leuk 14: S111-S113.

17. Kuo S, Debnam J, Fuller G, de Groot J (2009) Wernicke's encephalopathy: an under-recognized and reversible cause of confusional state in cancer patients. Oncology 76:10-18.

18. Food and Nutrition Board, Institute of Medicine: Thiamine (1998) In: Dietary reference intakes for thiamine, riboflavin, niacin, vitamin-B6, vitamin B12, pantothenic acid, biotin, and choline. Washington, DC, National Academy Press, pp: $58-86$

19. Ghorbani A, Fatehi F, Soltanzadeh A, Hamidieh A, Vahabi Z (2012) Wernicke's Encephalopathy in a Young Girl Suffering from Acute Myeloblastic Leukemia. Iran J Pediatr 22: 574-575.

20. Lacasse L, Lum C (2004) Wernicke encephalopathy in a patient with T-cel leukemia and severe malnutrition. Can J Neurol Sci 31: 97-98.

21. La Spina M, Catania R, Nigro LL, Grandi CD, Palmucci S, et al. (2010) Neurological complications during treatment of childhood cancer: mind Wernicke encephalopathy. Pediatr Hematol Oncol 27: 320-323.

22. Messina G, Quartarone E, Console G, Irrera G, Martino M, et al. (2007) Wernicke's encephalopathy after allogeneic stem cell transplantation. Tumori 93: 207-209. 
Citation: Becilli M, Pagano A, Mallio CA, Annibali O, Armiento D, et al. (2017) Wernicke's Encephalopathy in A Young Adult Affected by T Cell Acute Lymphoblastic Leukemia and lleotiphlytis with Review of the Literature. J Blood Lymph 7: 182. doi: 10.4172/2165-7831.1000182

Page 5 of 5

23. Steinberg A, Gorman E, Tannenbaum J (2014) Thiamine deficiency in stem cell transplant patients: a case series with an accompanying review of the literature. Clin Lymphoma Myeloma Leuk, pp: S111-113.

24. Muwakkit S, Al-Aridi C, Saab R, Hourani R, Yazbeck N, et al. (2009)
Wernicke's encephalopathy during total parenteral nutrition in a child with acute lymphoblastic leukemia and acute pancreatitis. Neuropediatrics 40: 249-251.

25. Trueg A, Borho T, Srivastava S, Kiel P (2013) Thiamine deficiency following umbilical cord blood transplant. Nutr Clin Pract 28: 223-225. 